\title{
PELAKSANAAN COOPERATIVE LEARNING MODEL PADA MATA KULIAH MEDIA PEMBELAJARAN ABK BAGI MAHASISWA BERKEBUTUHAN KHUSUS PRODI PENDIDIKAN KHUSUS FKIP UNIVERSITAS PGRI ADIBUANA SURABAYA
}

\author{
Muhammad Nurrohman Jauhari \\ Universitas PGRI Adi Buana Surabaya \\ Muhammadnurrohmanjauhari@gmail.com \\ Dian Puspa Dewi \\ Universitas PGRI Adi Buana Surabaya \\ Dianpuspadewi90@gmail.com
}

\begin{abstract}
Abstrak
Universitas PGRI Adibuana Surabaya (Unipa Surabaya) merupakan salah satu perguruan tinggi yang menjalankan amanat UU Nomor 8 Tahun 2016 pasal 10 ayat a tentang hak penyandang disabilitas untuk mendapat pendidikan di jenjang perguruan tinggi. Konsekuensinya, Unipa Surabaya berusaha memberikan pelayanan baik akademik dan non akademik kepada mahasiswa berkebutuhan khusus, termasuk di Prodi Pendidikan Khusus terdapat 2 mahasiswa dengan gangguan penglihatan dan 1 mahasiswa dengan gangguan fisik (handfoot). Pemberian layanan tersebut, dicerminkan dalam pembelajaran pada mata kuliah media pembelajaran ABK dengan menerapkan cooperative learning model. Penelitian ini merupakan jenis penelitian kulaitatif deskripstif, dimana peneliti berusaha mendeskripsikan proses pembelajaran dengan menerapkan cooperative learning model dalam pembelajaran mata kuliah media pembelajaran ABK. Berdasarkan hasil penelitian dapat disimpulkan bahwa pembelajaran dengan cooperative learning modeldapat berjalan dengan baik, terbukti mahasiswa berkebutuhan khusus terlibat secara aktif dalam pembelajaran, selain itu teman sebaya juga turut membantu mereka selama pembelajaran berlangsung.
\end{abstract}

Kata kunci: cooperative learning model, mahasiswa berkebutuhan khusus

\section{PENDAHULUAN}

Mahasiswa berkebutuhan

khusus memiliki hak untuk menempuh pendidikan pada jenjang perguruan tinggi. Permenristekdikti No 46 Tahun 2017 Pendidikan Khusus dan Layanan Khusus Pasal 1 Ayat 3 dijelaskan bahwa mahasiswa berkebutuhan khusus adalah mahasiswa yang memiliki keterbatasan fisik, intelektual, mental, sensorik, dan/atau yang memiliki potensi kecerdasan dan bakat istimewa. Mereka yang memiliki keterbatasan pada beberapa aspek kehidupannya mempunyai hak yang sama dalam mengakses pendidikan pada jenjang pendidikan tinggi. Terlebih pemerintah melalui UU Nomor 8 Tahun 2016 tentang penyandang disabilitas pasal 10 ayat a 
disampaikan bahwa penyandang disabilitas berhak mendapatkan pendidikan yang bermutu pada satuan pendidikan di semua jenis, jalur dan jenjang pendidikan secara inklusif dan khusus.

Pemerintah

semakin

memudahkan akses pendidikan bagi mahasiswa berkebutuhan khusus, hal ini dibuktikan dengan semakin banyaknya jumlah mahasiswa berkebutuhan khusus yang menempuh pendidikan di perguruan tinggi. Hal tersebut berdampak pada perguruan tinggi yang menerima mahasiswa berkebutuhan khusus untuk dapat memberikan layanan pendidikan yang layak dan dapat mengembangkan potensi mereka. Permen Ristekdikti No 46 Tahun 2017 tentang Pendidikan Khusus dan Layanan Khsuus Pasal 8 Ayat 1 mengatur bahwa Perguruan Tinggi menfasilitasi pembelajaran dan penilaian sesuai dengan kebutuhan mahasiswa berkebutuhan khusus tanpa mengurangi mutu hasil pembelajaran. Berdasarkan peraturan tersebut sudah menjadi barang tentu perguruan tinggi yang telah menerima mahasiswa berkebutuhan khusus harus memberikan layanan pendidikan yang sama dengan mahasiswa lainnya.

Layanan yang diberikan seyogyanya dapat mengakomodir karakteristik dan kebutuhan mahasiswa selama berada di lingkungan perguruan tinggi, baik dalam kegiatan akademik maupun non akademik. Sebagai bentuk peran serta perguruan tinggi dalam memberikan layanan yang layak bagi mahasiswa berkebutuhan khusus, khususnya dalam layanan akademik salah satunya adalah menyediakan perangkat pembelajaran yang sesuai dengan karakteristik dan kebutuhan mereka. Permen no 46 tahun 2017 pasal 8 ayat 2 mengatur pembelajaran yang diperuntukan bagi mahasiswa berkebutuhan khusus perlu dilakukan penyesuaian perangkat pembelajaran yag terdiri dari materi, alat/media pembelajaran, proses pembelajaran dan/atau penilaian. Selain perangkat pembelajaran.

Hal tersebut juga dilakukan oleh peneliti yang menjadi salah satu dosen pengampu mata kuliah media pembelajaran ABK di Prodi Pendidikan Khusus FKIP Unipa Surabaya. Peneliti berusaha menyusun perangkat pembelajaran yang terdiri dari materi, alat/media pembelajaran, proses pembelajaran dan/atau penilaian yang tertuang dalam Silabus dan RPP mata kuliah media pembelajaran ABK. Di dalam proses perkuliahan tersebut diterapkan cooperative learning model yang melibatkan seluruh mahasiswa termasuk mahasiswa berkebutuhan khusus untuk memecahkan masalah yang diberikan pada mata kuliah media pembelajaran ABK pokok bahasan jenis-jenis media 
pembelajaran. Adapun tujuan dari penelitian ini adalah untuk mengetahui proses pelaksanaan cooperative learning model pada mata kuliah media pembelajaran ABK bagi mahasiswa berkebutuhan khusus Prodi Pendidikan Khusus FKIP Unipa Surabaya.

\section{KAJIAN LITERATUR}

\section{Mahasiswa berkebutuhan khusus}

Mahasiswa merupakan seseorang yang mengenyam pendidikan pada jenjang Strata 1 (S1) dan Pascasarjana. Permen Ristekdikti No 46 Tahun 2017 Mahasiswa berkebutuhan khusus merupakan mahasiswa yang memiliki keterbatasan fisik, intelektual, mental, sensorik, dan/atau yang memiliki potensi kecerdasan di atas rata-rata. Mahasiswa berkebutuhan khusus yang mengenyam pendidikan pada peguruan tinggi berhak mendapatkan pelayanan fasilitas yang sama dengan yang didapatkan oleh mahasiswa lainnya.

Sama seperti individu berkebutuhan khusus di jenjang pendidikan dasar dan pendidikan menengah, klasifikasi kebutuhan khusus adalah sama. Masih dikutip dari Permen Ristekdikti No 46 Tahun 2017 bahwa mahasiswa berkebutuhan khusus mencakup mahasiswa tunanetra, tunarungu, tunagrahita, tunadaksa, gangguan komunikasi, lamban belajar, kesulitan belajar spesifik, gangguan spektrum autis dan gangguan perhatian serta hiperaktif. Mahasiswa berkebutuhan khusus tersebut memiliki keterbatasan pada aspek perkembangan tertentu, sehingga pemberian layanan mahasiswa berkebutuhan khusus diberikan sesuai dengan karakteristik masing-masing mahasiswa.Sehingga dalam menentukan prodi atau jurusan tertentu harus disesuaikan dengan karakteristik mempertimbangkan kelebihan dan kekurangan mahasiswa.

Efendi (2016) menjelaskan klasifikasi mahasiswa berkebutuhan khusus sesuai dengan klasifikasi anak berkebutuhan khusus di jenjang pendidikan dasar dan menengah adalah sebagai berikut, a) Tunantera adalah individu yang mengalami gangguan daya penglihatannya, berupa kebutaan menyeluruh atau sebagian, dan walaupun telah diberi pertolongan dengan alat-alat bantu khusus, mereka masih tetap memerlukan pelayanan pendidikan khusus. Anak dengan gangguan penglihatan terbagi menjadi dua yaitu: anak dengan buta total (blind) dan anak yang masih memiliki sisa penglihatan (low vision; b) Tunarungu adalah individudengan kondisi dimana dalam proses mendengar terdapat satu atau lebih organ telinga bagian luar, organ telinga bagian tengah, dan organ telinga bagian dalammengalami gangguan atau kerusakan disebabkan penyakit, 
kecelakaan, atau sebab lain yang tidak diketahui sehingga organ tersebut tidak dapat menjalankan fungsinya dengan baik; c) Tunagrahita merupakan individu yang secara nyata mengalami hambatan dan keterbelakangan perkembangan mental intelektual jauh di bawah rata-rata sedemikian rupa sehingga mengalami kesulitan dalam tugas-tugas akademik, komunikasi maupun sosial, dan karenanya memerlukan layanan pendidikan khusus; d) Tunadaksa ialah individu yang mengalami kelainan atau cacat yang menetap pada alat gerak (tulang, sendi, otot) sedemikian rupa sehingga memerlukan pelayanan pendidikan khusus; e) Individu dengan hambatan emosi dan perilaku dikenal merupakan individu yang mengalami kesulitan dalam penyesuaian diri dan tingkah laku tidak sesuai dengan norma-norma yang berlaku dalam lingkungan kelompok usia maupun masyarakat pada umumnya, sehingga merugikan dirinya maupun orang lain, dan karenanya memerlukan pelayanan pendidikan khusus demi kesejahteraan dirinya maupun lingkungannya; f) Gangguan spektrum autis adalah kelainan perkembangan yang secara signifikan berpengaruh terhadap komunikasi verbal dan non verbal serta interaksi sosial, umumnya terjadi pada usia sebelum usia tiga tahun, yang memiliki pengaruh jelek terhadap kinerja pendidikan anak; g) Lamban belajar atau slow learner adalah siswa yang lambat dalam proses belajar, sehingga ia membutuhkan waktu yang lebih lama dibandingkan sekelompok siswa lain yang memiliki taraf potensi intelektual yang sama; h) Kesulitan belajar atau learning disability adalah ketidakmampuan belajar mengacu pada gejala dimana siswa tidak mampu belajar atau menghindari belajar, sehingga hasil belajar di bawah potensi intelektualnya. IQ dari anak berkesulitan belajar berada pada ratarata dan bahkan ada yang di atas ratarata; dan i) anak cerdas istimewa dan bakat istimewa merupakan kelompok individu yang memiliki kemampuan intelektual tinggi, juga menunjukkan penonjolan kecakapan khusus yang bidangnya berbeda-beda antara anak yang satu dengan anak lainnya.

Di Prodi Pendidikan Khusus FKIP Unipa Surabaya terdapat dua jenis hambatan dari mahasiswa berkebutuhan khusus yaitu mahasiswa berkebutuhan khusus dengan gangguan penglihatan dan gangguan fisik.

\section{Cooperative Learning Model}

Pembelajaran merupakan sebuah usaha yang disengaja oleh seorang pendidik untu mengupayakan perubahan pada peserta didik, misal perubahan informasi pengetahuan, pengalaman dan tingkah laku yang mengarah pada hal yang lebih baik. Banyak hal yang menjadi cakupan 
proses pembelajaran, salah satunya adalah model pembelajaran. Trianto (2010:51) menjelaskan maksud dari model pembelajaran sebagai sebuah perencanaan ataupun pola yang dimanfaatkan sebagai panduan dalam merencanakan dan mengelola pembelajaran di kelas. Sebagai sebuah pola, model pembelajaran memiliki beberapa aspek yang terkait dengan perencanaan dan pelaksanaan pembelajaran terdiri dari strategi, teknik, metode, bahan, media dan alat penilaian pembelajaran.

Model pembelajaran terdiri dari beberapa jenis, salah satunya adalah model pembelajaran kooperatif. Pembelajaran kooperatif merupakan pembelajaran yang mendayagunakan peran siswa untuk saling bekerja sama antar siswa dalam menyelesaikan sebuah permasalahan yang diberikan oleh pendidik. Nurdyansyah dan Fahyuni (2016) menjelaskan bahwa pembelajaran kooperatif adalah pola pembelajaran yang dirancang pendidik agar peserta didik bekerja dalam kelompok kecil yang heterogen secara kolaboratif. Anggota kelompok yang heterogen memiliki pengertian bahwa peserta didik dalam satu kelompok memiliki karakteristik dan kemampuan yang beragam. Sehingga dalam kelompok inilah peserta didik dituntut untuk bekerja sama satu sama lain untuk menyelesaikan masalah, peserta didik akan bekerja sesuai dengan kapasitas yang dimilki dan saling berkolaborasi.

Dilengkapi pendapat Rusman (2010) menjelaskan bahwa model pembelajaran kooperatif ialah bentuk pembelajaran yang dilakukan melalui sharing atau berbagi dalam proses pembelajaran antar peserta didik, sehingga dapat menyamakan persepsi atas pengetahuan yang diperoleh. Selain itu proses sharing ini dapat meningkatkan bahkan memperluas interaksi peserta didik, baik antar anggota kelompok, kelompok lain dan guru, interaksi ini disebut dengan multiplle way traffic comunication.

Mengingat model pembelajaran terdiri dari beragam macamnya, sehingga beradarkan pemaparan di atas dan beberapa pendapat ahli lain model ini memiliki ciri khas yang membedakan dengan macam model pembelajaran. Sanjaya (2007) terdapat karaktersitik utama dari model pembelajaran kooperatif adalah sebagai berikut.

a. Pembelajaran secara tim

Tim merupakan sarana dalam mencapai tujuan. Oleh karena itu, tim harus dapat membuat setiap peserta didik belajar dan berkontribusi dalam menyelesaikan masalah yang diberikan oleh pendidik.

b. Didasarkan pada manajemen kooperatif 
Model pembelajaran ini memiliki tiga fungsi manajemen yaitu; 1) fungsi manajemen sebagai perencanaan pelaksanaan menunjukan bahwa pembelajaran kooperatif dilaksanakan sesuai dengan pembelajaran yang telah direncakanan, 2) fungsi manajemen sebagai organisasi diartikan bahwa model pembelajaran ini memerlukan perencanaan yang matang agar proses pembelajaran dapat terlaksanaka secara efektif, dan 3) fungsi manaejmen sebagai kontrol, artinya bahwa dalam pembelajaran perlu ditetapkan terlenih dahulu indikator keberhasilan melalui bentuk tes maupun nontes.

c. Kemauan untuk bekerja sama

Kerja sama merupakan roh dalam model pembelajaran kooperatif ini. Sehingga, jika pembelajaran ingin mencapai tujuannya, maka pendidik dapat menstimulasi peserta didik untuk menumbuhkan kemauannya dalam bekerja sama. Melalui kerja sama antar anggota kelompok, maka model pembelajaran koopeartif yang telah direncakan dapat dilaksanakan

d. Keterampilan bekerja sama Model pembelajaran kooperatif dapat melatih dan meningkatkan keterampilan peserta didik dalam bekerja sama dengan tim. Seyogyanya kerja sama merupakan keterampilan yang tidak hanya diperlukan dalam menyelsaikan tugas kelompok saja namun diperlukan pada semua aspek kehidupan seseorang.

Pembelajaran kooperatif dicirikan oleh struktur tugas, tujuan, dan penghargaan kooperatif. Siswa yang bekerja dalam situasi pembelajaran kooperatif didorong dan/atau dikehendaki untuk bekerja sama pada suatu tugas bersama dan mereka harus mengordinasikan usahanya untuk menyelesaikan tugasnya. Dalam penerapan pembelajaran kooperatif, dua atau lebih individu saling tergantung satu sama lain untuk mencapai satu penghargaan bersama.

Model pembelajaran kooperatif dikembangkan untuk mencapai setidaktidaknya tiga tujuan pembelajaran penting, yaitu hasil belajar akademik, penerimaan terhadap keragaman dan pengembangan keterampilan sosial. Tujuan dari pembelajaran kooperatif adalah untuk mengerjakan kepada siswa ketrampilan kerja sama dan kolaborasi. Dalam pembelajaran kooperatif tidak hanya mempelajari materi saja. Namun, siswa juga harus mempelajari ketrampilan-ketrampilan khusus yang disebut ketrampilan kooperatif. Keterampilan kooperatif ini berfungsi untuk melancarkan hubungan, kerja dan tugas. Peranan hubungan kerja dapat dibangun dengan 
mengembangkan komunikasi antar aktivitas, karakteristik, perubahan, anggota kelompok, sedangkan peranan hubungan, kesamaan, dan perbedaan tugas dilakukan dengan membagi tugas dengan fenomena lain (Sukmadinata, antar anggota kelompok selama 2012).

kegiatan.

\section{METODE PENELITIAN}

Metode penelitian ini

\section{HASIL DAN PEMBAHASAN}

Pelaksanaan penelitian dilaksanakan selama 2 kali dalam dua menggunakan metode kualitatif minggu, yaitu pada Jumat, 5 dan 12 deskriptif. Tujuan dari penelitian ini adalah untuk mengetahui proses pelaksanaan cooperative learning model pada mata kuliah media pembelajaran ABK bagi mahasiswa berkebutuhan khusus Prodi Pendidikan Khusus FKIP Unipa Surabaya. Subjek penelitian adalah mahasiswa Prodi Pendidikan Khusus FKIP Unipa Surabaya angkatan 2017, dimana dalam angkatan tersebut terdapat 2 mahasiswa gangguan penglihatan dan 1 mahasiswa dengan gangguan fisik (handfoot). Pengambilan data melalui observasi, wawancara tidak terstruktur, dan dokumentasi. Penelitian diskriptif bertujuan untuk Oktober 2018. Materi perkuliahaan yang sedang berlangsung ketika penelitian dilaksanakan adalah JenisJenis Media Pembelajaran (media visual, audio dan audio visual). Peneliti yang merupakan dosen mata kuliah tersebut menerapkan model pembelajaran kooperatif. Hal ini dikarenakan sesuai dengan keadaan kelas, dimana anggota kelas merupakan heterogen terlebih terdapat mahasiswa berkebutuhan khusus di dalamnya. Seperti yang diketahui di atas bahwa model pembelajaran kooperatif merupakan model pembejalaran yang mendeskripsikan atau menggambarkan mengkomodasikan karakteristik peserta didik yang heterogen.

fenomena-fenomena yang ada berupa

Peneliti menerapakan sintaks model pembelajaran kooperatif dalam perkuliahan Media Pembelajaran ABK materi Jenis-Jenis Media Pembelajaran. berikut dijelaskan sintaks model pembelajaran pada pertemuan I (Jumat, 5 Oktober 2018) sebagai berikut.

\begin{tabular}{|c|c|}
\hline SINTAKS & KEGIATAN PEMBELAJARAN \\
\hline $\begin{array}{l}\text { Sintaks } 1 \\
\text { Menyampaikan tujuan } \\
\text { perkuliahan dan } \\
\text { memotivasi mahasiswa }\end{array}$ & $\begin{array}{l}\text { Dosen menyampaikan tujuan perkuliahan yang akan } \\
\text { dicapai pada kegiatan perkuliahan dan menekankan } \\
\text { pentingnya topik yang akan dipelajari dan memotivasi } \\
\text { mahasiswa. }\end{array}$ \\
\hline $\begin{array}{l}\text { Sintaks } 2 \\
\text { Menyajikan informasi }\end{array}$ & $\begin{array}{l}\text { Dosen menyajikan informasi atau materi kepada } \\
\text { mahasiswa dengan jalan demonstrasi atau melalui } \\
\text { bahan bacaan }\end{array}$ \\
\hline Sintaks 3 & Dosen menjelaskan kepada mahasiswa bagaimana \\
\hline
\end{tabular}




\begin{tabular}{|l|l|}
\hline $\begin{array}{l}\text { Mengorganisasikan kalam } \\
\text { mahasiswa ke Kelompok } \\
\text { Kelompok-kelompok Belajar }\end{array}$ & $\begin{array}{l}\text { caranya membentuk kelompok-kelompok belajar dan } \\
\text { membimbing setiap kelompok agar melakukan tarmisi } \\
\text { secara efektif dan efisien. }\end{array}$ \\
\hline $\begin{array}{l}\text { Sintaks 4 } \\
\text { Membimbing } \\
\text { bekerja dan Belajar }\end{array}$ & $\begin{array}{l}\text { Dosen membimbing kelompok-kelompok belajar pada } \\
\text { saat mahasiswa mengerjakan tugas mereka }\end{array}$ \\
\hline $\begin{array}{l}\text { Sintaks 5 } \\
\text { Evaluasi }\end{array}$ & $\begin{array}{l}\text { Dosen mengevaluasi hasil belajar tentang materi yang } \\
\text { telah dipelajari atau masimg-masing kelompok } \\
\text { mempresentasikan hasil kerjanya }\end{array}$ \\
\hline $\begin{array}{l}\text { Sintaks 6 } \\
\text { Memberikan Penghargaan }\end{array}$ & $\begin{array}{l}\text { Dosen mencari cara-cara untuk menghargai baik upaya } \\
\text { maupun hasil belajar individu dan kelompok }\end{array}$ \\
\hline
\end{tabular}

diadaptasi dari Nurdyansyah dan Fahyuni (2016)

Penjelasan:

1. Dosen menyampaikan tujuan kepada mahasiswa yaitu agar mahasiswa dapat menjelaskan jenis-jenis media pembelajaran secara umum. Mahasiswa diharapkan dapat memahami tujuan pembelajaran yang disampaikan dosen

2. Dosen menyajikan informasi umum terkait jenis-jenis media pembelajaran. Adapun jenis media pembelajaran yang dijelaskan dosen adalah media audio, visual dan audio visual. Di sisi lain mahasiswa diharapkan dapat memahami jenis-jenis media pembelajaran yang disampaikan dosen. Untuk memastikan pemahaman mahasiswa tersebut dosen memberikan pertanyaan terkait materi.

3. Dosen membagi kelas menjadi 3 kelompok kecil berdasarkan jenis media pembelajaran yang akan dibahas dalam kelompok masing-maisng. Dosen mengupayakan dalam setiap kelompok terdapat 1 mahasiswa berkebutuhan khusus. kelompok audio terdapat mahasiswa tunanetra, kelompok audio visual mahasiswa tunanetra dan visual adalah mahasiswa dengan handfoot. Dosen meminta masing-maisng kelompok membuat analisis masing-masing jenis media dan mencari contoh jenis medianya.

4. Dosen membimbing mahassiswa dalam proses diskusi yang dilakukan mahasiwa terkait tugas kelompok yaitu membuat analisis masing-masing jenis media dan mencari contoh jenis medianya. Dosen memastikan bahwa ada kerja sama antar anggota kelompok, khususnya mahasiswa berkebutuhan khusus. Mahasiswa berkebutuhan khusus harus tetap dilibatkan dan berperan dalam diskusi yang dilakukan oleh kelompk.

5. Dosen mengevaluasi hasil kerja mahasiswa. Mahasiswa diminta mempresentasikan hasil analisis masing-masing jenis media dan mencari contoh jenis medianya

6. Dosen memberikan apresiasi pada presentasi yang dilakukan oleh kelompok.

Pada perkuliahan yang berlangsung pada pertemuan I (Jumat, 5 Oktober 2018) diamati oleh peneliti bahwa mahasiswa dapat melakukan kerja sama dengan 
cukup baik. Namun porsi keterlibatan mahasiwa berkebutuhan khusus dalam kelompok masih terbatas. Sehingga dosen merencanakan menerapkan model pembelajaran kooperatif kembali pada pertemuan berikutnya dengan tugas yang berbeda.

Berikut merupakan sintaks model pembelajaran yang direncanakan peneliti dalam pertemuan II (12 Oktober 2018).

\begin{tabular}{|c|c|}
\hline SINTAKS & KEGIATAN PEMBELAJARAN \\
\hline $\begin{array}{l}\text { Sintaks } 1 \\
\text { Menyampaikan tujuan } \\
\text { perkuliahan dan } \\
\text { memotivasi mahasiswa }\end{array}$ & $\begin{array}{l}\text { Dosen menyampaikan tujuan perkuliahan yang akan } \\
\text { dicapai pada kegiatan perkuliahan dan menekankan } \\
\text { pentingnya topik yang akan dipelajari dan memotivasi } \\
\text { mahasiswa. }\end{array}$ \\
\hline $\begin{array}{l}\text { Sintaks } 2 \\
\text { Menyajikan informasi }\end{array}$ & $\begin{array}{l}\text { Dosen menyajikan informasi atau materi kepada } \\
\text { mahasiswa dengan jalan demonstrasi atau melalui } \\
\text { bahan bacaan }\end{array}$ \\
\hline $\begin{array}{l}\text { Sintaks } 3 \\
\text { Mengorganisasikan } \\
\text { mahasiswa ke dalam } \\
\text { Kelompok-kelompok } \\
\text { Belajar }\end{array}$ & $\begin{array}{l}\text { Dosen menjelaskan kepada mahasiswa bagaimana } \\
\text { caranya membentuk kelompok-kelompok belajar dan } \\
\text { membimbing setiap kelompok agar melakukan tarmisi } \\
\text { secara efektif dan efisien. }\end{array}$ \\
\hline $\begin{array}{l}\text { Sintaks } 4 \\
\text { Membimbing Kelompok } \\
\text { bekerja dan Belajar }\end{array}$ & $\begin{array}{l}\text { Dosen membimbing kelompok-kelompok belajar pada } \\
\text { saat mahasiswa mengerjakan tugas mereka }\end{array}$ \\
\hline $\begin{array}{l}\text { Sintaks } 5 \\
\text { Evaluasi }\end{array}$ & $\begin{array}{l}\text { Dosen mengevaluasi hasil belajar tentang materi yang } \\
\text { telah dipelajari atau masimg-masing kelompok } \\
\text { mempresentasikan hasil kerjanya }\end{array}$ \\
\hline $\begin{array}{l}\text { Sintaks } 6 \\
\text { Memberikan Penghargaan }\end{array}$ & $\begin{array}{l}\text { Dosen mencari cara-cara untuk menghargai baik upaya } \\
\text { maupun hasil belajar individu dan kelompok }\end{array}$ \\
\hline
\end{tabular}

diadaptasi dari Nurdyansyah dan Fahyuni (2016)

Penjelasan:

1. Dosen menyampaikan tujuan kepada mahasiswa yaitu agar mahasiswa dapat mendemonstrasikan jenis-jenis media pembelajaran dalam kegiatan pembelajaran dengan siswa.

2. Dosen menyajikan informasi umum terkait jenis-jenis media pembelajaran serta mengulas analisis media pembelajaran pada pertemuan sebelumnya.

3. Dosen membagi kelas menjadi 3 (sama dengan kelompok sebelumnya). Dosen mengupayakan dalam setiap kelompok terdapat 1 mahasiswa berkebutuhan khusus. kelompok audio terdapat mahasiswa tunanetra, kelompok audio visual mahasiswa tunanetra dan visual adalah mahasiswa dengan handfoot. Dosen 
meminta masing-maisng kelompok merencanakan kegiatan untuk mendemostrasikan media yang sudah dianalisis pada pertemuan sebelumnya.

4. Dosen membimbing mahassiswa dalam mempersiapkan demosntrasi yang akan dilaksanakan. Dosen memastikan keterlibatan mahasiswa berkebutuhan khusus dengan memberikan mereka peran aktif dalam kegiatan demosntrasi yang akan dilakukan.

5. Dosen mengevaluasi hasil kerja mahasiswa. Mahasiswa diminta mendemostrasikan jenis media pembelajran kepada siswa di kelas. Pada kegiatan ini, mahasiwa berkebutuhan khusus turut aktif dimana ada yang berperan menajdi siswa dan ada yang berperan menjadi guru dalam kelompok masingnya masing-maisng. Sehingga setiap anggota kelompok betul-betul merencanakan demostrasi secara matang untu keterlibatan semau anggota kelpmpok.

6. Dosen memberikan apresiasi pada demontrasi yang dilakukan oleh kelompok.

Pada pertemuan II (12 Oktober

2018) diperoleh hasil bahwa model pembelajaran kooperatif dapat diterapkan dengan baik pada kelas yang sifatnya heterogen, terlebih pada mahasiswa berkebutuhan khusus di Prodi Pendidikan Khusus FKIP Unipa Surabaya. Hal tersebut dengan pencapaian skor instrumen observasi sebesar $90 \%$.

Oleh karena itu model pembelajaran kooperatif yang telah dilaksanakan dapat dikategorikan berhasil oleh peneliti. Model pembelajaran kooperatif dapat memfasilitasi mahasiswa dalam melakukan kerja sama antar kelompok. Sesuai dengan pendapat Sanjaya (2008) bahwa model pembelajaran kooperatif memiliki manfaat selain untuk meningkatkan hubungan sosial, menumbuhkan sikap tolerasni dan menghargai pendapat orang lain model pembelajaran kooperatif juga dapat merealisasikan kebutuhan siswa dalam belajar berfikir kreatif, memecahkan masalah dan mengintegrasikan pegetahuan yang didapat dengan pengalaman peserta didik.

Trianto (2010) menambahkan bahwa model pembelajaran koopeartfi memiliki kelebihan antara lain; a) dapat mengembangkan kemampuan mengungkapkan gagasan atau ide secara verbal dan membandingkan dengan ide orang lain, b) dapat membantu peserta didik untuk respek pada orang lain dan menyadari akan segala keterbatasan serta menerima perbedaan, dan c) merupakan strategi pembelajran yang cukup ampuh dalam meningkatkan prestasi akademik atau hasil belajar peserta didik.

\section{SIMPULAN}

Berdasarkan penelitian yang telah dilakukan oleh peneliti dapat 
diperoleh kesimpulan bahwa model pembelajaran cooperative atau cooperative learning model berhasil diterapkan pada perkuliahan media pemnbelajaran khususnya jenis-jenis media pembelajaran untuk mahasiswa berkebutuhan khusus di Prodi Pendidikan Khusus FKIP Unipa Surabaya. Hal tersebut dapat dilihat bahwa mahasiswa dapat melakukan kerja sama yang baik dalam menyelesaikan masalah terkait jenisjenis media pembelajaran. Kerja sama dapat dilihat tidak hanya antar mahasiswa reguler namun juga antar mahasiswa reguler dan mahasiswa berkebutuhan khusus. Dalam demontrasi penggunaan media pembelajaran mahasiswa berkebutuhan khusus memiliki peran aktif baik menjadi guru ataupun menjadi murid pada demonstrasi kelompoknya masing-masing.

\section{DAFTAR PUSTAKA}

Efendi, Mohammad. 2006. Pengantar Psikopedagogik Anak Berkelainan. Jakarta: Bumi Aksara.
Nurdyansyah dan Fahyuni, Eni Fariyarul. 2016. Inovasi Model Pembelajaran sesuai Kurikulum 2013. Sidoarjo: Nizamia Learning Center.

Permen Ristekdikti No 46 Tahun 2017 tentang Pendidikan Khusus dan Layanan Khsusus.

Rusman. 2010. Model-model Pembelajaran: Mengem Profesionalisme Guru (Jakarta: PT Raja Grafindo Persada).

Sanjaya, Wina. 2008 Strategi Pembelajaran Berorientasi Standar ProsesPendidikan (Jakarta: Kencana Prenada Media Group)

Sukmadinata, N.S. 2012. Metode Penelitian Pendidikan. Bandung: PT Remaja Rosdakarya.

Trianto. 2010. Mendesain Model Pembelajaran InovatifPrograsif.Jakarta:Prenada Media UNNES PRESS.

Undang-Undang Republik Indonesia Nomor 8 Tahun 2016 Tentang Penyandang Disabilitas. 